\title{
O USTROJU SAMORZAॄDU MIASTA STOŁECZNEGO WARSZAWY
}

$\mathrm{Na}$ przestrzeni 25 lat istnienia odrodzonego samorządu terytorialnego w Polsce samorząd warszawski przechodził kolejne przeobrażenia. Zwłaszcza w pierwszej połowie tego okresu toczyły się intensywne prace ustawodawcze, ścierały się różnorodne koncepcje i szukano optymalnych rozwiązań ustrojowych. Ewolucja ustroju stolicy miała specyficzny charakter - stosowano bowiem tu konstrukcje niespotykane w innych jednostkach samorządu terytorialnego w Polsce. Istotne modyfikacje dotyczyły podziału kompetencji pomiędzy szczeblem ogólnomiejskim i dzielnicowym oraz pozycji organu wykonawczego miasta, w mniejszym stopniu zmiany objęły organ stanowiący.

\section{OD FEDERALIZMU DO CENTRALIZMU}

Każda z trzech tzw. ustaw warszawskich prezentowała inne podejście do prawnoustrojowej pozycji dzielnicy. Przekrój stosowanych koncepcji można określić następująco: od samodzielności naznaczonej mankamentem słabej więzi ze wspólnota związkowa, nacechowanej swego rodzaju separatyzmem lokalnym, poprzez umiarkowaną centralizację, aż do pełnej unifikacji w postaci jednej gminy miasta na prawach powiatu z silnymi jednostkami pomocniczymi - dzielnicami.

W 1990 r. przyjęto jednolite rozwiązania ustrojowe dla wszystkich gmin, bez względu na ich charakter miejski lub wiejski, jak również ze względu na liczbę mieszkańców. Dlatego część samorządowców z Warszawy zaproponowała odrębną ustawę dla stolicy, zgodnie z którą Warszawa byłaby jednostka samorządu gminnego i wojewódzkiego (jeszcze wówczas nie było szczebla powiatowego ${ }^{1}$ ). Początkowo uważano, że propozycja ta sprzeczna jest z ustawa o samorządzie terytorialnym ${ }^{2}$, ale w końcu zgodzono się, że: po pierwsze - artykuł 38 tej ustawy dopuszcza odrębność ustroju gmin, które wykonywały zadania o szczególnym charakterze; po drugie - art. 64 dopuszczał konstrukcję prawną obligatoryjnego związku gmin. Te dwie możliwości legły u podstaw inicjatywy opracowania odrębnej ustawy dla m.st. Warszawy.

\footnotetext{
${ }^{1}$ Zarówno w Polsce, jak i Europie Zachodniej duże miasta mają szczególny status. Zob. H. Gronkiewicz-Waltz, Warszawa obligatoryjnym zwiazkiem gmin, „Gazeta Samorządowa” 1990, nr 4-5, s. 14 .

${ }^{2}$ Ustawa z 8 marca 1990 r. o samorzadzie terytorialnym, Dz. U. Nr 16, poz. 95 ze zm. (obecna nazwa: ustawa o samorządzie gminnym) oraz ustawa z 18 maja 1990 r. o ustroju samorządu miasta stołecznego Warszawy, Dz. U. Nr 34, poz. 200.
} 
$\mathrm{Na}$ mocy pierwszej ustawy warszawskiej m.st. Warszawa było związkiem dzielnic-gmin (dalej jako: Związek), który posiadał osobowość prawną (art. 1 ust. 1). Dzielnice-gminy m.st. Warszawy były gminami w rozumieniu przepisów ustawy o samorządzie terytorialnym (art. 1 ust. 2).

Do zakresu działania dzielnicy-gminy m.st. Warszawy należały wszystkie sprawy publiczne o znaczeniu lokalnym niezastrzeżone ustawami na rzecz innych podmiotów (art. 5). Do zakresu działania i zadań Związku należały natomiast sprawy wynikające ze stołecznego charakteru m.st. Warszawy oraz sprawy publiczne o znaczeniu ogólnomiejskim spośród zadań gminy określonych w art. 7 ustawy o samorządzie terytorialnym, a w szczególności te, których wykonanie przekraczało możliwości dzielnic-gmin m.st. Warszawy i wymagało współdziałania międzykomunalnego (art. 6 ust. 1).

Przyjęte w omawianej ustawie rozwiązania dawały silną pozycję i niezależność dzielnicom-gminom m.st. Warszawy. Każda z nich prowadziła własna politykę komunalna, miała własny budżet i wykonywała zadania o charakterze lokalnym. Mankamentem pierwszej ustawy warszawskiej był nieprecyzyjny podział zadań pomiędzy poszczególne dzielnice-gminy m.st. Warszawy i Związek, który to podział opierał się na niedookreślonych zwrotach, takich jak „sprawy publiczne o znaczeniu ogólnomiejskim” czy „sprawy publiczne o znaczeniu lokalnym". Prowadziło to do licznych sporów kompetencyjnych pomiędzy poszczególnymi dzielnicami-gminami m.st. Warszawy oraz pomiędzy nimi a Związkiem, co wpływało negatywnie na sprawność w realizowaniu zadań na obu poziomach. Paraliż decyzyjny i kompetencyjny uwidocznił się szczególnie np. w braku realizacji ważnych zadań inwestycyjnych.

Problemy, które uwidoczniły się w funkcjonowaniu ustroju m.st. Warszawy, dały silny asumpt do rozpoczęcia prac nad reformą tego ustroju, w trakcie których pojawiły się trzy główne koncepcje. Wariant metropolitalny zakładał powstanie gminy centralnej, która miała obejmować swoim zasięgiem teren zbliżony do Warszawy z 1938 r., pokryty zwartą zabudową miejską i tworzyć wraz z otaczającymi ją odrębnymi, posiadającymi własną osobowość prawna, względnie samodzielnymi gminami - Warszawski Związek Metropolitalny ${ }^{3}$.

Proponowano też przekształcenie Warszawy w jedna gminę z jednostkami pomocniczymi - dzielnicami, które miały jedynie realizować decyzje podjęte przez organy m.st. Warszawy ${ }^{4}$.

Pojawił się także tzw. projekt burmistrzowski, przewidujący zachowanie dotychczasowego zdecentralizowanego podziału na dzielnice-gminy i doprecyzowanie zadań Związku5.

Ostatecznie podjęto próbę uwzględnienia po części wszystkich prezentowanych rozwiązań i zdecydowano pozostać przy koncepcji podziału Warszawy na kilka niezależnych gmin, choć jednocześnie utworzono dużą gminę Warszawa-Centrum, która pełnić miała rolę centrum metropolii warszawskiej, i doprecyzowano zadania ogólnomiejskie i stołeczne.

${ }^{3}$ Zob. M. Niziołek, Problemy ustroju aglomeracji miejskich ze szczególnym uwzględnieniem Warszawy, Warszawa 2008, s. 105; S. Faliński, Warszawskie warianty, zrealizowane $i$ niezrealizowane koncepcje ustroju Warszawy w latach 1990-2002, Siedlce 2013, s. 16-17.

${ }^{4}$ Zob. S. Faliński, op. cit., s. 20.

5 Zob. ibidem, s. 22. 
Zgodnie z drugą ustawą warszawska ${ }^{6} \mathrm{~m}$.st. Warszawa było związkiem komunalnym w rozumieniu ustawy o samorządzie terytorialnym (art. 1 ust. 1) tworzonym już nie przez dzielnice-gminy, a wyłącznie gminy warszawskie: Warszawę-Bemowo, Warszawę-Białołękę, Warszawę-Bielany, Warszawę-Centrum z dzielnicami, Warszawę-Rembertów, Warszawę-Targówek, Warszawę-Ursus, Warszawę-Ursynów, Warszawę-Wawer, Warszawę-Wilanów oraz Warszawę-Włochy (art. 1 ust. 2), przy czym, tak jak zakładano w projekcie metropolitalnym, gmina Warszawa-Centrum stanowiła centrum metropolii otoczone przez mniejsze - zarówno pod względem terytorialnym, jak i pod względem liczby mieszkańców - gminy o dużym stopniu samodzielności. W art. 2 drugiej ustawy warszawskiej precyzyjnie określono zadania związane ze stołecznym charakterem, wskazując, że należą one do zakresu działania gmin warszawskich. Dookreślono również zakres działania m.st. Warszawy (art. 5), zaliczając do jego zadań sprawy o wyraźnie ogólnomiejskim charakterze ${ }^{7}$.

Była to zatem kolejna próba znalezienia odpowiedniej równowagi pomiędzy takim usytuowaniem władzy, aby znajdowała się ona jak najbliżej obywatela, a koniecznością zapewnienia sprawności i możliwości jej wykonywania.

Wyeksponowanie - zarówno pod względem administracyjnym, jak i politycznym (przede wszystkim przez pozycję Prezydenta m.st. Warszawy) gminy Warszawa-Centrum, które zapewniało jej pozycję centrum metropolii, miało być zarówno bodźcem integracji wewnątrzwarszawskiej, jak i ułatwiać nawiązywanie, a następnie pogłębianie współpracy z gminami okołowarszawskimi.

Istotna dla tak ukształtowanego ustroju m.st. Warszawy była rola Prezydenta m.st. Warszawy, który zgodnie z art. 9 ust. 1 drugiej ustawy warszawskiej był przewodniczącym Zarządu, tj. organu wykonawczego m.st. Warszawy, a jednocześnie jednoosobowym organem wykonawczym gminy Warszawa-Centrum wybieranym przez Radę Gminy Warszawa-Centrum.

Ustrój m.st. Warszawy ukształtowany drugą ustawą warszawską uległ istotnej zmianie po wejściu w życie ustawy z 18 marca 1999 r. o zmianie ustawy o ustroju miasta stołecznego Warszawy ${ }^{8}$, na mocy której zlikwidowano unię personalną gminy Warszawa-Centrum i m.st. Warszawy oraz wprowadzono w gminie Warszawa-Centrum ogólny model władzy wykonawczej w postaci kolegialnego zarządu.

Likwidacja silnej pozycji Prezydenta m.st. Warszawy doprowadziła do rozbicia dotąd w miarę jednolitego rdzenia decyzyjnego - skupionego wokół gminy Warszawa-Centrum - na dwa obozy: gminę Warszawę-Centrum i m.st. Warszawę. Skutkiem tego powiększył się rozdźwięk pomiędzy dwoma niejed-

${ }^{6}$ Dzielnice m.st. Warszawy (gminy) w drugiej ustawie warszawskiej - z 25 marca $1994 \mathrm{r}$. o ustroju miasta stołecznego Warszawy (Dz. U. Nr 48, poz. 195 ze zm.).

${ }^{7}$ Planowanie strategii rozwoju i zagospodarowania; realizacja przedsięwzięć publicznych, zwłaszcza o charakterze infrastrukturalnym, mających znaczenie dla całego miasta lub dla kilku gmin warszawskich, w tym w szczególności sprawy inicjowania i rozwijania współpracy międzygminnej na rzecz realizacji tych przedsięwzięć; wspomaganie przedsięwzięć publicznych; wspomaganie gmin warszawskich w celu wyrównywania rażących dysproporcji w sferze zaspokajania potrzeb zbiorowych wspólnot samorządowych.

${ }^{8}$ Dz. U. Nr 92, poz. 1044. 
nolitymi poziomami sprawowania władzy: ogólnowarszawskim i lokalnym gminnym.

Prezydent RP, który skierował nowelizację drugiej ustawy warszawskiej do Trybunału Konstytucyjnego, zasadnie zwrócił uwagę, że „obecny ustrój Warszawy nie tworzy warunków do wykonywania zadań, jakie stoją przed metropolią stołeczną".

Niewątpliwą zaletą ustroju m.st. Warszawy ukształtowanego drugą ustawą warszawską było wyważenie proporcji pomiędzy tendencją centralizacyjna a decentralizacyjna. Ponadto powierzchnia i liczba ludności gmin warszawskich, a także ich wewnętrzna spójność (poza gminą Warszawa-Centrum), co do układu osadniczego i przestrzennego zapewniały efektywność realizacji zadań lokalnych.

Podobnie jednak jak na gruncie pierwszej ustawy warszawskiej, problemem była sprawna realizacja zadań ogólnowarszawskich, w tym wynikających ze stołecznego charakteru miasta. Spory kompetencyjne, które uwidoczniły się zwłaszcza po reformie ustroju m.st. Warszawy wprowadzonej ustawa z 18 marca 1999 r., odbijały się niekorzystnie na realizacji istotnych dla tak dużego i rozwijającego się miasta, jakim była Warszawa, inwestycji - przede wszystkim infrastrukturalnych, jak i w zapewnieniu spójnej koncepcji zagospodarowania przestrzennego. Gmina Warszawa-Centrum nie spełniała swej roli jako centrum metropolii, które miało oddziaływać na pozostałe gminy warszawskie oraz obszar okołowarszawski. Doprowadziło to do skomplikowania już i tak mało czytelnej struktury organizacyjnej miasta. W konsekwencji dokonanej zmiany w m.st. Warszawie istniało 11 gmin ze swoimi organami, funkcjonowały władze m.st. Warszawy oraz powiatu warszawskiego ${ }^{9}$, a gmina Warszawa-Centrum podzielona była na dzielnice.

W pojawiajacych się w latach 1994-2002 propozycjach gruntownej zmiany, a wręcz stworzenia od podstaw struktury administracyjnej Warszawy, można wyróżnić trzy główne modele ustrojowe. Postulowano likwidację odrębności gmin warszawskich i centralizację władzy. Koncepcję tę uzasadniano przede wszystkim usprawnieniem wykonywania władzy i ograniczeniem zbędnej biurokracji.

Proponowano również zachowanie ustroju policentrycznego z samodzielnymi gminami warszawskimi, przy czym uzasadniano, że rozdzielenie władzy pomiędzy mniejsze gminy zapewnia sprawność realizacji zadań lokalnych i dobre rozpoznanie pojawiających się na danym obszarze problemów, a ponadto na przekór koncepcji jednej gminy wskazywano, że zarządzanie gmina obejmujacca swoim obszarem całe miasto nie musi wcale okazać się sprawne i efektywne.

Ciekawą koncepcją był również pomysł stworzenia obszaru metropolitalnego obejmujacego gminy warszawskie jako centrum metropolii oraz obszary sasiednie, m.in. powiaty pruszkowski, legionowski i otwocki. Ostatecznie zdecydowano o likwidacji odrębności gmin warszawskich i o utworzeniu w ich miejsce dzielnic - jednostek pomocniczych m.st. Warszawy.

\footnotetext{
${ }_{9}^{9}$ Zob. M. Niziołek, op. cit., s. 115-116.
} 
Zgodnie z trzecią ustawą warszawską ${ }^{10} \mathrm{~m}$. st. Warszawa jest gminą majaca status miasta na prawach powiatu (art. 1 ust. 1), w której utworzenie jednostek pomocniczych - dzielnic m.st. Warszawy jest obligatoryjne (art. 5 ust. 1). Dotychczasowe gminy warszawskie ${ }^{11}$ stały się dzielnicami m.st. Warszawy (art. 14).

Niezbędnym następstwem likwidacji związku komunalnego m.st. Warszawy, gmin warszawskich oraz powiatu warszawskiego była centralizacja aparatu pomocniczego władzy wykonawczej - powstał Urząd Miasta Stołecznego Warszawy (art. 18 ust. 1).

Trzecia ustawa warszawska przyjęła odmienny od dotychczasowego model ustroju - koncepcję jednej gminy. Jego istotą jest likwidacja kilku ośrodków władzy na korzyść władzy centralnej - ogólnowarszawskiej. Z tego powodu bywa stawiany zarzut, że proces decyzyjny jest zbyt scentralizowany, zbyt oddalony od mieszkańców.

Jednakże trudno podzielić powyższą opinię, postanowienia trzeciej ustawy warszawskiej zagwarantowały bowiem dzielnicom m.st. Warszawy dużą samodzielność, a tym samym nie naruszyły zasady decentralizacji władzy publicznej. Dzielnice otrzymały m.in. swój własny katalog zadań lokalnych, wyodrębnione w ramach budżetu m.st. Warszawy załączniki dzielnicowe, a więc pewną swobodę finansową. To one decydują w praktyce, czy potrzebny jest żłobek czy droga.

Istnienie jednostek pomocniczych - dzielnic m.st. Warszawy jest obowiązkowe (art. 5 ust. 1 trzeciej ustawy warszawskiej), a nie jak w innych gminach - fakultatywne (art. 5 ust. 1 ustawy z 8 marca 1990 r. o samorządzie gminnym ${ }^{12}$ ). Rozwiąanie to zapewnia ciagłość i trwałość wyodrębnienia terytorialno-organizacyjnego określonych części Warszawy, choć już nie w ramach podziału zasadniczego, ale pomocniczego. Jak wskazuje się w literaturze przedmiotu, podział pomocniczy ma rzeczywisty wpływ na demokratyzację życia społecznego mieszkańców danego obszaru ${ }^{13}$, a ponadto w jego ramach realizuje się te zadania, których wykonywanie w ramach jednostek podziału zasadniczego jest bądź wyraźnie nieracjonalne, bądź mało skuteczne ${ }^{14}$.

Polityczny aspekt decentralizacji przejawia się w możliwości wyboru przez społeczność lokalną swojego politycznego przedstawicielstwa. Trzecia ustawa warszawska gwarantuje, że wybory do rady dzielnicy m.st. Warszawy przeprowadza się co do zasady według takich samych zasad jak te dotyczące wyboru radnych do rady $\mathrm{w}$ mieście na prawach powiatu (art. 7 ust. 2), a nie

${ }^{10}$ Ustawa z 15 marca 2002 r. o ustroju miasta stołecznego Warszawy, Dz. U. Nr 41, poz. 361 ze zm.

11 Warszawa-Bemowo, Warszawa-Białołęka, Warszawa-Bielany, Warszawa-Rembertów, Warszawa-Targówek, Warszawa-Ursus, Warszawa-Ursynów, Warszawa-Wawer, Warszawa-Wilanów, Warszawa-Włochy) oraz dzielnice-gminy Warszawa-Centrum (Mokotów, Ochota, Praga-Południe, Praga-Północ, Śródmieście, Wola, Żoliborz).

${ }_{12}$ Dz. U. 2013, poz. 594 ze zm.

${ }^{13}$ M. Augustyniak, Jednostki pomocnicze gminy, Warszawa 2010, za: M. Elżanowski, Przestanki reform podziału terytorialnego: studium z nauki administracji i prawa administracyjnego, Warszawa 1982, s. 38.

14 Ibidem. 
jak w innych gminach na zasadach określonych przez radę gminy w statucie jednostki pomocniczej (art. 35 ust. 3 pkt 2 ustawy o samorządzie gminnym). Rozwiązanie to zapewnia mieszkańcom wybór swojej reprezentacji politycznej także na poziomie dawnych gmin warszawskich ${ }^{15}$, a obecnie jednostek pomocniczych - dzielnic.

Z uwagi jednak na to, że rada dzielnicy m.st. Warszawy wybiera swój zarząd, w tym burmistrza (art. 10 ust. 1), występuje ryzyko rodzaju kohabitacji nie tylko na linii Prezydent m.st. Warszawy - Rada m.st. Warszawy, ale także na linii Prezydent m.st. Warszawy - zarząd dzielnicy. Sytuacja taka może negatywnie odbijać się na efektywności sprawowania władzy. Jest to jednak koszt dokonanej w $2002 \mathrm{r}$. zmiany ustroju m.st. Warszawy - przekształcenia gmin warszawskich w stosunkowo samodzielne dzielnice oraz bezpośredniego wyboru Prezydenta m.st. Warszawy.

Finansowy aspekt decentralizacji przejawia się natomiast $\mathrm{w}$ posiadaniu przez organy lokalne środków finansowych na realizację własnej polityki ${ }^{16}$. Gospodarka finansowa dzielnic m.st. Warszawy opiera się na stanowiących obligatoryjny element uchwały budżetowej m.st. Warszawy załącznikach dzielnicowych, które podlegają zaopiniowaniu przez rady poszczególnych dzielnic (art. 12 ust. 1 i 2 trzeciej ustawy warszawskiej). Środki finansowe przeznaczone do dyspozycji dzielnicy w załączniku dzielnicowym nie moga być mniejsze niż określony procent dochodów z obszaru danej dzielnicy m.st. Warszawy planowanych w budżecie m.st. Warszawy. Rada m.st. Warszawy, przekazując do dyspozycji dzielnicy środki finansowe, powinna uwzględnić potrzebę zapewnienia skuteczności decentralizacji zadań gminy, równomiernego rozwoju wszystkich dzielnic m.st. Warszawy oraz maksymalnej możliwości zaspokojenia zbiorowych potrzeb ich wspólnot. Przekazywanie dzielnicy m.st. Warszawy zadań następuje wraz z zapewnieniem środków wystarczających na ich realizację.

Rozwiązanie takie nie daje wprawdzie dzielnicom m.st. Warszawy całkowitej samodzielności ekonomicznej, ale z drugiej strony otwiera drogę do sprawiedliwej redystrybucji dóbr pomiędzy dzielnice.

W trzeciej ustawie warszawskiej wskazano, że do zadań dzielnic m.st. Warszawy należą sprawy lokalne (art. 11 ust. 2), oraz podano przykładowe rodzaje spraw, które powinny być załatwiane na ich szczeblu, m.in.: utrzymywanie i eksploatacja gminnych zasobów lokalowych, dzielnicowych obiektów administracyjnych, podejmowanie we własnym zakresie działań na rzecz zaspokajania zbiorowych potrzeb wspólnoty mieszkańców dzielnicy. Tym samym tylko niektóre zadania zostały przekazane dzielnicom z mocy ustawy (dekoncentracja prawna). W znacznym zakresie to organom miasta pozostawiono decyzję co do zakresu zadań i kompetencji przekazywanych jednostkom pomocniczym (dekoncentracja faktyczna). Zadania dzielnic m.st. Warszawy precyzowane sa w ich statutach. Zgodnie z nimi do zakresu ich działania należą sprawy lokalne o zasięgu dzielnicowym, m.in. inwestycje, działalność kulturalna, architektura i budownictwo, promocja dzielnicy.

15 Funkcjonujacych na podstawie pierwszej i drugiej ustawy warszawskiej.

${ }^{16}$ N. Gajl, Finanse i gospodarka lokalna na świecie, Warszawa 1993, s. 12. 
Nadto w wykonaniu art. 11 ust. 1 trzeciej ustawy warszawskiej Rada m.st. Warszawy 18 grudnia 2008 r. podjęła tzw. uchwałę kompetencyjną ${ }^{17}$, której przedmiotem jest precyzyjne określenie zadań, jakie realizować maja dzielnice m.st. Warszawy. Był to kolejny przejaw decentralizacji zwiększający ukształtowaną ustawowo samodzielność jednostek pomocniczych. Nastapiła znaczna dekoncentracja zadań nałożonych na m.st. Warszawę i większe zaangażowanie jednostek pomocniczych w ich wykonywanie. Uchwała kompetencyjna szczegółowo określiła szeroki katalog spraw przekazywanych do wykonywania organom dzielnic m.st. Warszawy, w efekcie w sposób kompleksowy doprowadziła do unifikacji zakresu ich działania w skali całego miasta. Nastapiło istotne przesunięcie administracji lokalnej bliżej mieszkańców. Zoptymalizowano możliwość zaspokojenia zbiorowych potrzeb wspólnot w dzielnicach, gdyż przeniesiono na ich szczebel wykonywanie szeregu tzw. podstawowych spraw, z jakimi mieszkańcy zwracają się do organów administracji samorządowej.

Obecny ustrój m.st. Warszawy zapewnia odpowiednia proporcję pomiędzy sprawnością wykonywania władzy a jej przeniesieniem do dzielnicy, tak aby była ona wykonywana najbliżej wspólnot lokalnych. Jest natomiast kwestia otwarta, które elementy tego modelu ustrojowego wymagają doprecyzowania czy korekty - proces ten zresztą ciagle postępuje, o czym świadczą chociażby wprowadzane zmiany statutów dzielnic m.st. Warszawy, regulaminu organizacyjnego Urzędu Miasta Stołecznego Warszawy czy też wspomnianej uchwały kompetencyjnej.

\section{ORGAN WYKONAWCZY: OD KOLEGIALNOŚCI DO MONOKRATYCZNOŚCI}

W ustroju m.st. Warszawy dostrzec można również znaczącą zmianę w zakresie pozycji i funkcjonowania jego organu wykonawczego, które ewoluowały od dualizmu i kolegialności do monokratyczności.

W pierwszej ustawie warszawskiej przyjęto na poziomie Związku, że jego organy wykonawcze to Zarząd Warszawy i Prezydent Warszawy. Wybory Prezydenta Warszawy były pośrednie i dwustopniowe. Rada Warszawy na pierwszym posiedzeniu wybierała kandydatów na to stanowisko oraz zwoływała Zgromadzenie Wyborcze składające się z radnych wszystkich dzielnic. Zgromadzenie Wyborcze wybierało Prezydenta bezwzględną większościa głosów w głosowaniu tajnym, w obecności co najmniej $2 / 3$ składu. Zgromadzenie Wyborcze na wniosek Rady mogło odwołać Prezydenta Warszawy w trybie przewidzianym dla jego wyboru. Prezydent wykonywał administrację publiczną w zakresie zadań Związku w sprawach niezastrzeżonych dla innych orga-

17 Uchwała nr XLVI/1422/2008 w sprawie przekazania dzielnicom m.st. Warszawy do wykonywania niektórych zadań i kompetencji m.st. Warszawy. 
nów Związku. Artykuł 28 ust. 1 pierwszej ustawy warszawskiej przewidywał domniemanie kompetencji Prezydenta Warszawy w zakresie zadań administracji publicznej, natomiast wyliczenie jego uprawnień w ust. 2 tego przepisu wskazywało na ograniczenie jego roli na gruncie samorządowym do spraw organizacyjnych. W ramach swoich zadań Prezydent przewodniczył Zarządowi Warszawy i kierował jego pracami, reprezentował Związek na zewnątrz, wykonywał funkcje reprezentacyjne związane ze stołecznym charakterem Warszawy oraz był zwierzchnikiem służbowym pracowników Urzędu Warszawy oraz kierowników jednostek organizacyjnych Związku.

Większość kompetencji merytorycznych typowych dla organu wykonawczego wykonywał Zarząd Warszawy, składajacy się z 3 wiceprezydentów i 5 członków. Przy czym skład Zarządu mógł jedynie w 1/3 pochodzić spoza grona Rady Warszawy. Zarząd Warszawy był wybierany przez Radę Warszawy spośród kandydatów przedstawionych przez Prezydenta Warszawy. Członkowie Zarządu Warszawy uczestniczyli w posiedzeniach Rady Warszawy. Do kompetencji Zarządu należało m.in. opracowywanie projektu statutu Związku, projektu budżetu Związku, projektów programów rozwoju Warszawy, projektów uchwał Rady Warszawy i ich wykonywanie, gospodarowanie mieniem i wykonywanie budżetu Związku.

Pośredniość wyboru wszystkich organów Związku ograniczała wpływ mieszkańców na ich skład. Zabrakło elementu bezpośredniości na poziomie ogólnomiejskim. Wprowadzenie dualizmu organu wykonawczego było niejasne, zwłaszcza w kontekście normy stanowiącej domniemanie kompetencji Prezydenta Warszawy przy jednoczesnym przyznaniu większości uprawnień Zarządowi Warszawy. Brak było wskazania ustawowych przyczyn odwołania Prezydenta Warszawy. Kwestia ta pozostawała w gestii Rady Warszawy i Zgromadzenia Wyborczego. Zarząd Warszawy natomiast można było odwołać jedynie w przypadku nieudzielenia absolutorium. Zarząd Warszawy był silnie związany z Radą Warszawy, składał się w znacznej mierze z jej członków, a przez to pozbawiony był, przynajmniej częściowo, niezależności i samodzielności. Na kształt Zarządu Warszawy miały wpływ zarówno rozkład sił w samej Radzie Warszawy, składającej się z delegowanych radnych dzielnic, jak i interesy poszczególnych dzielnic-gmin.

Labilność panującego ustroju została szybko dostrzeżona i już w 1991 r. pojawił się pierwsze propozycje jego zmiany ${ }^{18}$. W drugiej ustawie warszawskiej zrezygnowano z funkcjonującego dotychczas dualizmu władzy wykonawczej. Organem wykonawczym w m.st. Warszawie ustanowiono Zarząd m.st. Warszawy, składający się z Prezydenta m.st. Warszawy jako jego przewodniczącego oraz wiceprezydentów. Wiceprezydenci nie musieli być członkami Rady m.st Warszawy. Wybierała ich i odwoływała Rada na wniosek Prezydenta.

Do zadań Zarządu należało w szczególności przygotowywanie projektów i wykonywanie uchwał Rady, prowadzenie bieżacych spraw, w tym zarzą-

18 Tak S. Faliński, Warszawski samorzad terytorialny w latach 1990-2002. Geneza, ustrój, idee ustrojowe, aktywność, Warszawa 2013, s. 105. 
dzanie mieniem należącym do m.st. Warszawy. Prezydenta m.st. Warszawy wybierała Rada Gminy Warszawa-Centrum w głosowaniu tajnym bezwzględną większością głosów w obecności co najmniej 2/3 ustawowego składu rady. Kandydatów na Prezydenta mogli zgłaszać radni gminy Warszawa-Centrum oraz rady gmin warszawskich. Rada m.st. Warszawy mogła rekomendować na to stanowisko jednego lub więcej kandydatów spośród zgłoszonych przez wyżej wymienione podmioty albo zgłosić własnego kandydata. Podkreślenia wymaga, że Prezydent m.st. Warszawy był jednocześnie jednoosobowym organem wykonawczym gminy Warszawa-Centrum. Tym samym utworzono unię personalną pomiędzy gminą Warszawa-Centrum a związkiem komunalnym - m.st. Warszawą. Do wykonywania zadań w gminie Warszawa-Centrum Prezydent m.st. Warszawy powoływał i odwoływał swoich zastępców, a także określał zakres udzielonych im pełnomocnictw.

Druga ustawa warszawska wprowadziła istotne novum, jakim był monokratyczny organ wykonawczy gminy Warszawa-Centrum. Był to jedyny taki przypadek w kraju. Silnie związanie personalne organów wykonawczych m.st. Warszawy i gminy Warszawa-Centrum wynikało w znacznej mierze z jej specyfiki. Gmina Warszawa-Centrum odróżniała się istotnie od pozostałych gmin warszawskich, zarówno liczbą mieszkańców, jak i poziomem dochodów czy funkcjami realizowanymi w ramach aglomeracji. Jak słusznie wskazał Trybunał Konstytucyjny ${ }^{19}$, łączenie dwóch kierowniczych stanowisk w osobie Prezydenta m.st. Warszawy mogło ograniczać możliwości zajmowania się przez niego sprawami gminy Warszawa-Centrum i utrudniać dbałość o interes tej gminy w konfrontacji z interesami całego miasta. Przyjęta monokratyczność organu wykonawczego i wiążące się z tym następstwa w sprawowaniu władzy wskazały na potrzebę podjęcia prac ustawodawczych w kierunku zwiększenia sprawności i efektywności zarządzania jednostkami samorządu terytorialnego. Również większą uwagę zwrócono na kwestię zapewnienia stabilności i ciagłości władzy wykonawczej, o czym świadczy uszczegółowienie trybu odwołania Prezydenta m.st. Warszawy. Jednocześnie pozostawiono silne związanie Prezydenta m.st. Warszawy oraz Zarządu m.st. Warszawy z wybierajacymi ich organami stanowiącymi. Regulacje omawianej ustawy oprócz zniesienia dualizmu organu wykonawczego m.st. Warszawy wzmacniały pozycję Prezydenta m.st. Warszawy.

Tak ukształtowana pozycja ustrojowa organu wykonawczego m.st. Warszawy została zmieniona ustawą nowelizujaca z 18 marca 1999 r. Zniesiono odrębność ustrojową gminy Warszawa-Centrum, wprowadzając w niej funkcjonujący już w innych gminach warszawskich kolegialny, pochodzący z wyborów pośrednich zarząd. Natomiast Zarząd m.st. Warszawy miał być wybierany w całości przez Radę m.st. Warszawy. Zrezygnowano więc z unii personalnej łączącej m.st. Warszawę i gminę Warszawa-Centrum. Zgodzić się należy $\mathrm{z}$ opinią ${ }^{20}$, że „zniesienie tej unii personalnej przesądzało o rychłej, ostatecznej likwidacji ustroju metropolitalnego. W Warszawie nie mogły długo, dobrze

\footnotetext{
19 Wyrok TK z 24 marca 1998 r., K 40/97, OTK 1998, Nr 2, poz. 12.

20 S. Faliński, Warszawskie warianty..., s. 47.
} 
i zgodnie funkcjonować dwa niezależne od siebie tak potężne politycznie i gospodarczo ośrodki władzy publicznej, jak miasto stołeczne Warszawa i gmina Warszawa-Centrum".

W trzeciej ustawie warszawskiej oraz ustawie z 20 czerwca 2002 r. o bezpośrednim wyborze wójta, burmistrza i prezydenta miasta ${ }^{21}$ zrezygnowano z koncepcji kolegialnego organu wykonawczego gminy na rzecz koncepcji organu monokratycznego. W teorii ustroju przyjmuje się, że organy jednoosobowe powinny być powoływane tam, gdzie wymagana jest szybkość działania, operatywność, sprawne podejmowanie decyzji oraz ich wykonywanie ${ }^{22}$. Dlatego też model ten jest wykorzystywany w wielu państwach europejskich w przypadku organów wykonawczych jednostek samorządu terytorialnego ${ }^{23}$.

Wprowadzenie w trzeciej ustawie warszawskiej opisanego modelu ujednoliciło pod tym względem sytuację w stolicy na szczeblu ogólnomiejskim oraz $\mathrm{w}$ innych gminach $\mathrm{w}$ Polsce. Jako że m.st. Warszawa jest gminą na prawach powiatu, z obligatoryjnymi jednostkami pomocniczymi - dzielnicami, to zakres zadań i kompetencji organu wykonawczego wynika z ustawy o samorządzie gminnym. Prezydent m.st. Warszawy jest wybierany w wyborach bezpośrednich, a jego kadencja rozpoczyna się, co do zasady w dniu rozpoczęcia kadencji Rady m.st. Warszawy i upływa z dniem upływu jej kadencji. Prezydent wykonuje uchwały Rady i zadania gminy określone przepisami prawa. Do jego zadań należy w szczególności: przygotowywanie projektów uchwał Rady, określanie sposobu wykonywania uchwał, gospodarowanie mieniem komunalnym, wykonywanie budżetu, zatrudnianie i zwalnianie kierowników gminnych jednostek organizacyjnych. Przysługuje mu wyłączna inicjatywa uchwałodawcza w zakresie budżetu m.st. Warszawy, a w przypadku niecierpiącym zwłoki może wydać przepisy porządkowe w formie zarządzenia, które to podlega zatwierdzeniu na najbliższej sesji Rady.

Monokratyczność organu wykonawczego przyczyniła się do usprawnienia zarządzania na szczeblu gminnym. I co ważne, choć artykułowano szereg obaw, podejmowane przez organ wykonawczy decyzje nie maja charakteru arbitralnego czy też samowolnego, gdyż w znacznej mierze opierają się na konsultacjach społecznych, opiniach ekspertów i stanowiskach wypracowanych przez wyspecjalizowany aparat urzędniczy. Nie bez znaczenia pozostają również kompetencje kontrolne Rady m.st. Warszawy wyrażające się choćby w możliwości nieudzielenia Prezydentowi absolutorium. Obecnie obowiązujące przepisy, np. ustawa o dostępie do informacji publicznej, pozwalaja na bieżące monitorowanie działań władzy samorządowej przez obywateli. Mieszkańcy gminy maja również możliwość odwołania Prezydenta w drodze referendum. Mechanizm ten jest ściśle powiązany z bezpośredniością wybo-

21 Dz. U. Nr 113, poz. 984 ze zm.

22 Por. E. Olejniczak-Szałowska, Problematyka determinantów wyboru monokratycznego lub kolegialnego modelu organu wykonawczego na poszczególnych szczeblach jednostek samorzadu terytorialnego, w: M. Stec, K. Małysa-Sulińska (red.), Pozycja ustrojowa organów wykonawczych jednostek samorzadu terytorialnego, Warszawa, s. 33-34.

${ }^{23}$ Por. L. Rajca, Dysfunkcjonalne rozwiazania prawne w polskim samorzadzie terytorialnym, w: A. Lutrzykowski (red.), Samorzad terytorialny - ale jaki?, Toruń 2009, s. 138. 
ru organu wykonawczego. Przyjęty sposób wyłaniania Prezydenta wiąże się ze wzmocnieniem jego legitymacji w stosunku do tej wynikającej z wcześniej obowiązującej zasady pośredniości. To już nie organ stanowiący i kontrolny decyduje o odwołaniu Prezydenta Warszawy z piastowanego stanowiska, lecz członkowie wspólnoty samorządowej, choć Radzie m.st. Warszawy przysługuje prawo inicjowania takich działań. Obecna pozycja obu organów m.st. Warszawy, pochodzących z wyborów bezpośrednich, jednakowo silnie demokratycznie legitymizowanych, niejako mobilizuje te organy do prowadzenia dialogu z mieszkańcami i wypracowywania rozwiązań umożliwiających sprawne funkcjonowanie stolicy.

W omawianym kontekście nie sposób nie odnieść się do pojawiającego się $\mathrm{w}$ dyskusjach nad ustrojem gmin postulatu wprowadzenia zmian w pozycji ustrojowej organu wykonawczego przez postawienie go na czele rady gminy ${ }^{24}$. $\mathrm{Z}$ założenia, według rzeczników tych zmian, miałoby to rozwiązywać problem ewentualnego braku większościowego poparcia w radzie gminy dla działań organu wykonawczego i związanego z nim ewentualnego zablokowania zdolności gminy do wykonywania zadań publicznych. Proponowana zmiana nie wpłynęłaby korzystnie na pozycję ustrojową organów stolicy ani nie przyczyniłaby się do rozwiązania problemu możliwego paraliżu działania jednostki samorządu terytorialnego. W sytuacji gdy zarówno Prezydent, jak i Rada m.st. Warszawy pochodzą z wyborów bezpośrednich, przyznanie Prezydentowi kompetencji do kierowania pracami Rady nie zniweluje różnic w stanowiskach i poglądach obu organów czy też, czego nie można wykluczyć, także osobistej niechęci. Rola przewodniczącego Rady nie może polegać na ingerowaniu w swobodę decyzyjną radnych. Wypracowywanie porozumienia, wspólnych rozwiązań odbywa się również przy obecnie obowiązującym podziale zadań. Ustanowienie Prezydenta Warszawy przewodniczacym Rady doprowadziłoby do zatarcia granic pomiędzy organem stanowiąco-kontrolnym a wykonawczym i mogłoby wywołać daleko posunięte problemy związane z jednoznacznym oddzieleniem kompetencji obu podmiotów.

\section{ORGAN STANOWIĄCY: OD POŚREDNIOŚCI DO BEZPOŚREDNIOŚCI}

Zmiany, jakie następowały na przestrzeni 25 lat istnienia samorządu warszawskiego, objęły również swym zakresem organ stanowiący. Najbardziej widoczna różnica występuje pomiędzy pierwszą a drugą ustawą warszawską i dotyczy sposobu wyboru członków organu.

${ }^{24}$ J. Jagoda, Tryb wyboru organów wykonawczych a ich relacje $z$ organami stanowiacymi jednostek samorzadu terytorialnego, w: M. Stec, K. Małysa-Sulińska (red.), op. cit., s. 101; M. Kulesza, Konsolidacja zarzqdzania w samorzqdzie - wybrane zagadnienia. Uwagi do dyskusji, „Samorząd Terytorialny” 16, 2006, nr 7-8, s. 8-9. 
W pierwszej ustawie warszawskiej przyjęto, na poziomie związku dzielnic-gmin, że organem stanowiacym i kontrolnym była Rada Warszawy wybierana $\mathrm{w}$ wyborach pośrednich przez radnych dzielnic. Pośredni wybór Rady powodował, że nie było jasne, czy radny działa w interesie całej Warszawy, czy tylko dzielnicy, której rada go wybrała. Rada nie miała ani przewodniczącego, ani prezydium, a jej posiedzenia zwoływał Prezydent Warszawy. Do głównych kompetencji Rady należało uchwalenie statutu Związku, budżetu m.st. Warszawy oraz przyjmowanie sprawozdań z działalności finansowej Związku i udzielanie absolutorium Zarządowi z tego tytułu, uchwalanie wieloletnich programów rozwoju i planów zagospodarowania przestrzennego Warszawy, ustanawianie opłat za korzystanie z usług przedsiębiorstw, zakładów, instytucji, urządzeń ogólnomiejskich, jak również podejmowanie uchwał w sprawach majątkowych Związku, przekraczających zakres zwykłego zarządu.

Druga ustawa warszawska realizowała kolejny etap zmian w ustroju stolicy. Organem stanowiącym i kontrolnym m.st. Warszawy była Rada, w której skład wchodziło 68 radnych pochodzących z wyborów bezpośrednich. Bezpośredniość wyborów stanowiła krok w dobrym kierunku. Pozwalała społeczeństwu wpływać na kształt nie tylko organów dzielnicowych, ale i ogólnomiejskiej rady, utożsamiać się z wybranymi kandydatami, a także ich rozliczać $\mathrm{z}$ wykonywania mandatu. Legitymizacja płynąca $\mathrm{z}$ wyborów bezpośrednich uniezależniała organ stanowiący Warszawy od dzielnic, dając mu silniejsza pozycję, radnym zaś możliwość działania w interesie całego miasta, a nie tylko konkretnej dzielnicy. Wprowadzono również funkcję przewodniczącego i wiceprzewodniczaccych Rady, co miało wpływ na usprawnienie jej prac. Do wyłącznej właściwości Rady m.st. Warszawy należało m.in. uchwalanie statutu m.st. Warszawy, stanowienie o kierunkach działania Zarządu Miasta Stołecznego Warszawy oraz przyjmowania sprawozdań z jego działalności, uchwalanie budżetu m.st. Warszawy, rozpatrywanie sprawozdania z jego wykonania oraz podejmowanie uchwały $\mathrm{w}$ sprawie udzielenia lub nieudzielenia absolutorium Zarządowi z tego tytułu, podejmowanie uchwał w sprawach majątkowych m.st. Warszawy, przekraczajacych zakres zwykłego zarządu.

W trzeciej ustawie warszawskiej podtrzymano bezpośredniość wyboru członków Rady m.st. Warszawy. Składa się ona z 60 radnych wybieranych na czteroletnia kadencję; jako rada gminy funkcjonuje w znacznej mierze na podstawie ustawy o samorządzie gminnym. W ustawie o samorządzie gminnym ustanowiono domniemanie właściwości rady gminy we wszystkich sprawach pozostających w zakresie działania gminy, o ile ustawy nie stanowia inaczej. Jak wskazano w judykaturze ${ }^{25}$, domniemanie właściwości rady należy rozumieć w ten sposób, iż rada gminy jako organ o charakterze kolegialnym i wieloosobowym może podejmować działania związane ze stanowieniem (art. 15 ust. 1) lub kontrola (art. 18 ust. 1). Nie może natomiast podejmować czynności, które należą do sfery wykonawczej, gdyż byłoby to naruszeniem konstytucyjnej zasady podziału organów gminy na stanowiące i wykonawcze (art. 169 Konstytucji RP). Do wymienionych w ustawie o samorządzie gmin-

${ }^{25}$ Wyrok NSA oz. w Katowicach z 25 października 1999 r., I SA/Ka 1628/99, „Wspólnota” 2000, nr 42, s. 41. 
nym kompetencji rady należy m.in. uchwalanie statutu gminy, stanowienie o kierunkach działania Prezydenta oraz przyjmowanie sprawozdań z jego działalności, uchwalanie budżetu gminy, rozpatrywanie sprawozdania z wykonania budżetu oraz podejmowanie uchwały w sprawie udzielenia lub nieudzielenia absolutorium z tego tytułu, uchwalanie studium uwarunkowań i kierunków zagospodarowania przestrzennego gminy oraz miejscowych planów zagospodarowania przestrzennego, ustalanie zakresu działania jednostek pomocniczych, zasad przekazywania im składników mienia do korzystania oraz zasad przekazywania środków budżetowych na realizację zadań przez te jednostki, podejmowanie uchwał w sprawach majątkowych gminy przekraczających zakres zwykłego zarządu, określanie wysokości sumy, do której organ wykonawczy może samodzielnie zaciagać zobowiązania.

Przy obecnie funkcjonujacym modelu organu stanowiącego Rada m.st. Warszawy dysponuje silną legitymacja, płynącą z wyborów bezpośrednich, oraz ukierunkowana jest na działanie $\mathrm{w}$ interesie całego miasta, a nie tylko poszczególnych dzielnic.

\section{USTRÓJ WARSZAWY NA TLE USTROJU BERLINA I PARYŻA}

Warto pokrótce przedstawić i porównać z koncepcjami warszawskimi niektóre rozwiązania sprawowania władzy zastosowane w Berlinie oraz w Paryżu.

\section{Ustrój Berlina ${ }^{26}$}

Berlin jest jednym z krajów związkowych Republiki Federalnej Niemiec. Ustrój polityczny Niemiec oparty jest na zasadzie federalizmu - kraj ten jest federacją w dużej mierze niezależnych krajów związkowych (landów), przy czym trzy miasta - Berlin, Brema i Hamburg sa osobnymi krajami związkowymi - miastami wydzielonymi.

Nie jest wprawdzie uprawnione porównywanie niemieckich krajów związkowych do funkcjonujacych w Polsce województw, niemniej jednak - przenosząc dyskusję na poziom koncepcji ustrojowej - warto pamiętać, że wśród pomysłów zmiany ustroju Warszawy pojawił się i taki, zgodnie z którym miałaby się ona stać 17 województwem.

Berlin składa się z 12 dzielnic (Bezirk), które jednak nie stanowią niższego stopnia podziału zasadniczego (nie są samodzielnymi gminami), ale maja charakter pomocniczy, służą usprawnieniu wykonywania władzy. Obok administracji głównej sprawowanej przez Senat Berlina (Senat), ważną rolę spełniaja urzędy administracji dzielnicowej (Bezirksverwaltungen). Senat wykonuje zadania o charakterze ogólnomiejskim (np. bezpieczeństwo, finanse), natomiast wszystkie pozostałe zadania o charakterze lokalnym realizowane sa w dzielnicach, przy czym administracja dzielnicowa pozostaje pod kontrolą Senatu.

${ }^{26}$ W oparciu o Konstytucję krajową Berlina: Verfassung von Berlin vom 23. November 1995, „Gesetz- und Verordnungsblatt für Berlin” vom 28. November 1995, s. 779 (dalej jako: KK). 
Obecny podział administracyjny Berlina istnieje od $2001 \mathrm{r}$. Wcześniej miasto podzielone było na 23 dzielnice.

Centralizacja miała na celu usprawnienie wykonywania władzy, ograniczenie biurokracji i kosztów. Na tym przykładzie widać, że wysuwany przez niektórych postulat decentralizacji władzy w Warszawie, który miały być realizowany przez tworzenie rozdrobnionych ośrodków władzy, nie ma niestety przełożenia na efektywność jej wykonywania.

Władzę ustawodawczą w Berlinie sprawuje Izba Poselska (Abgeordnetenhaus) wybierana w wyborach bezpośrednich (art. 39.1 KK), władzę wykonawczą zaś Senat, na czele którego stoi burmistrz rządzący (Regierender Bürgermeister). Inaczej niż w m.st. Warszawie władza wykonawcza Berlina ma charakter kolegialny, a ponadto nie pochodzi z wyborów bezpośrednich. burmistrz rządzący jest bowiem wybierany bezwzględną większością głosów przez Izbę Poselska (art. 56.1 KK) i on z kolei powołuje i odwołuje pozostałych senatorów (art. 56.2 KK).

Rozwiązanie takie funkcjonowało w m.st. Warszawie do czasu wejścia w życie ustawy z 20 czerwca 2002 r. o bezpośrednim wyborze wójta, burmistrza i prezydenta miasta ${ }^{27}$. Co do zasady zapewnia ono skuteczną kontrolę władzy ustawodawczej nad władzą wykonawcza, ale jego minusem jest ryzyko dużego upolitycznienia i ograniczenia władzy wykonawczej. Aktualnie obowiązujący w Warszawie system bezpośredniego wyboru prezydenta miasta zapewnia niezależność w wykonywaniu władzy i umożliwia zachowanie bezstronności - niezależnie od aktualnej koniunktury politycznej, choć oczywiście w zależności od rozkładu sił politycznych istnieje ryzyko powstania konfliktu na linii prezydent - Rada m.st. Warszawy.

Mieszkańcy Berlina wybierają również swoje przedstawicielstwo dzielnicowe (Bezirksverordnetenversammlung). Inaczej jednak niż w Warszawie nie ma ono uprawnień uchwałodawczych, ale spełnia jedynie funkcje administracyjne - wybiera osoby tworzące urząd dzielnicy (Bezirksamt), na czele którego stoi burmistrz dzielnicy (Bezirksbürgermeister). Burmistrzowie dzielnic wraz z burmistrzem rządzącym tworzą Radę Burmistrzów (Rat der Bürgermeister), która jest organem doradczym Senatu Berlina (art. 68.2 KK).

Ustrój Berlina wykazuje pewne podobieństwa do ustroju m.st. Warszawy. Ma on podobnie jak w m.st. Warszawie charakter jednostopniowy (dzielnice nie są odrębnymi gminami). Takie ześrodkowanie władzy wpływa pozytywnie na jej funkcjonalność. Jedynie wykonanie zadań delegowane jest na szczeble niższe - dzielnicowe, jak najbliższe obywatelom. Z kolei wyodrębnienie organizacyjno-polityczne dzielnic Berlina jest mniejsze niż w m.st. Warszawie. Władze dzielnic pełnia jedynie rolę wykonawcza, a burmistrzowie dzielnic dodatkowo - doradczą względem Senatu. I warto w tym miejscu zaznaczyć, że, pomimo słabszej niż w m.st. Warszawie samodzielności organizacyjno-ustrojowej dzielnice Berlina sa zarówno terytorialnie, jak i pod względem liczby ludności większe niż dzielnice m.st. Warszawy, przykładowo najmniejsza (pod względem liczby mieszkańców) dzielnica Berlina (Spandau) liczy ok. 220 tys. mieszkańców.

27 Dz. U. Nr 113, poz. 984 ze zm. 


\section{Ustrój Paryża ${ }^{28}$}

Republika Francuska dzieli się administracyjnie na regiony, departamenty i gminy. Gminy francuskie sa zazwyczaj niewielkie zarówno terytorialnie, jak i pod względem liczby ludności. Zasada ta nie odnosi się jednak do dużych miast. Zgodnie z aktualnie obowiazująca ustawa z 31 grudnia 1982 r. o organizacji administracyjnej Paryża, Lyonu i Marsylii oraz o związkach współpracy międzygminnej (PLM), Paryż jest odrębnym 75 departamentem, który nie dzieli się na gminy, ale na 20 dzielnic (arrondissement municipal). Paryż jest miastem o podwójnych kompetencjach departamentalnych i gminnych.

Podobne rozwiązanie funkcjonuje aktualnie w Warszawie - jest ona gminą mająca status miasta na prawach powiatu (art. 1 ust. 1 trzeciej ustawy warszawskiej). Warto jednak zwrócić uwagę, że prezydent Warszawy (podobnie jak każdy wójt, burmistrz czy prezydent miasta w Polsce) jest organem władzy samorządowej, podczas gdy mer Paryża jest jednocześnie reprezentantem władzy centralnej i samorządowej. Ponadto prezydent Warszawy wybierany jest w wyborach powszechnych i bezpośrednich, podczas gdy w Paryżu mer wybierany jest przez Radę Paryża (Conseil de Paris).

Rozwiązanie przyjęte w Warszawie ma tę zaletę, że jej prezydent może być przez mieszkańców miasta traktowany jako przedstawiciel społeczności lokalnej, a nie urzędnik władzy centralnej. Jednakże fakt łączenia funkcji przedstawiciela władzy państwowej i samorządowej jest kwestia pewnej tradycji i ewolucji systemu politycznego w danym kraju. Warto pamiętać, że w Polsce samorządy realizują wiele zadań z zakresu administracji rządowej, niemniej jednak są to zadania zlecone, a zatem takie, które teoretycznie mogłyby być realizowane przez znajdujący się poza samorządem aparat wykonawczy.

Ponadto Rada Paryża funkcjonuje albo jako rada departamentu, albo jako rada gminy. W przypadku Warszawy przyjęto prostsze rozwiązanie, zgodnie z którym, z ustrojowego punktu widzenia, jest ona gmina, która realizuje jednocześnie zadania gminne i powiatowe (art. 1 ust. 1 trzeciej ustawy warszawskiej w związku z art. 92 ust. 2 ustawy z 5 czerwca 1998 r. o samorządzie powiatowym ${ }^{29}$ ). Oznacza to, że w Warszawie nie funkcjonują organy powiatu, a jedynie gminy (miasta na prawach powiatu) - z uwzględnieniem odrębności wprowadzonych trzecią ustawą warszawska.

Dzielnice Paryża nie stanowią odrębnych gmin, nie posiadają osobowości prawnej, nie posiadają własnego majątku. Podobnie jak w Berlinie służą lepszemu wykonywaniu zadań - zwłaszcza tych o charakterze lokalnym. Rada dzielnicy (conseil d’arrondissement) pochodzi z wyborów powszechnych, jednak ma charakter przede wszystkim opiniodawczo-doradczy.

\footnotetext{
${ }^{28}$ Na podstawie ustawy z 31 grudnia 1982 r. o organizacji administracyjnej Paryża, Lyonu i Marsylii oraz o związkach współpracy międzygminnej: La loi n 82-1169 du 31 décembre 1982 relative à l'organisation administrative du Paris, Marseille, Lyon et des établissments publics de coopération intercommunale (J.O. du 1 janvier 1983).

${ }^{29}$ Dz. U. 2013, poz. 595 ze zm.
} 


\section{PODSUMOWANIE}

1. Przedstawiona krótka charakterystyka organizacji władzy w Berlinie i Paryżu pokazuje, że każde miasto - mając różne doświadczenia czy odmienną tradycję prawnoustrojową - może odrębnie kształtować swój ustrój. Jednak w procesie formowania się ustroju miasta, co do zasady, przewijają się te same problemy, tzn. jak ma wyglądać wewnętrzna organizacja miasta, jak daleko idące kompetencje będą miały poszczególne organy, jaką niezależnością powinien dysponować organ wykonawczy miasta i z czyjego wyboru ma pochodzić.

2. Obecny ustrój Warszawy jest efektem ewolucji myślenia o sposobie konstrukcji ustroju władzy w warunkach dużego miasta, ciagłym zmierzaniem się z wyzwaniem stworzenia modelu optymalnego dla aktualnych warunków społeczno-terytorialno-ekonomicznych.

3. Warto jednak pamiętać, że to mieszkaniec i jego potrzeby wynikające z bycia częścią pewnej zbiorowości są najważniejszym punktem odniesienia. Określenie tych potrzeb winno być zawsze wstępem do rozważań o organizacji władzy, a ich realizacja - zwieńczeniem procesu budowy ustroju. Aktualnie wszelkie innowacje technologiczne (np. Internet) mają ogromny wpływ zarówno na relacje samorząd-mieszkańcy, jak i sposoby komunikacji między nimi. Mieszkańcy, zwłaszcza dużych miast, są coraz lepiej wykształceni i dysponując wiedza, jak zaspokajane są potrzeby gdzie indziej (w innych państwach), mają sprecyzowane oczekiwania.

4. Wydaje się, że ustrój m.st. Warszawy był adekwatny do czasu, w którym funkcjonował. Okres, kiedy dzielnice były gminami, przyczynił się do uświadomienia sobie wagi samorządności, a stopniowa centralizacja uświadomiła konieczność zaspokajania nie tylko potrzeb lokalnych, ale i ogólnomiejskich. Z pewnością ustrój wprowadzony w 2002 r. umożliwił absorpcję środków unijnych w wyjątkowo szerokim zakresie. Ustrój ten, jak przestawiono wyżej, jest podobny do ustroju innych stolic europejskich, jak chociażby Berlina czy Paryża.

prof. dr hab. Hanna Gronkiewicz-Waltz Uniwersytet Warszawski,

Prezydent Miasta Stołecznego Warszawy

hwaltz@wpia.uw.edu.pl

mgr Beata Jakacka

radca prawny, pracownik samorzqdowy

bjakacka@um.warszawa.pl 


\section{ON THE REGIME OF SELF-GOVERNMENT OF THE CAPITAL CITY OF WARSAW}

\section{Sum mary}

The evolution of the regime of the Capital City was very specific because its original regime differed from that of a typical unit of local self-government. Initially, Warsaw was an association of independent districts-municipalities, which - in order to improve the decision-making processes and exercise of competences - were eventually transformed into a municipal association of one large municipality (gmina) Warszawa-Centrum and 10 smaller municipalities. Subsequent changes included liquidation of the municipalities and creation of districts. The changes in the executive bodies led to another change, this time from a collegiate to a monocratic system of executive power. The most crucial change though, was the decision that a mayor be elected in direct elections. Currently, the regime in Warsaw is similar to the regime of such cities as Berlin or Paris. 
